\title{
Parental involvement and educational success in Kosovar families in Switzerland
}

\author{
Rosita Fibbi ${ }^{*}$ and Jasmine Truong
}

\author{
* Correspondence: \\ rosita.fibbi@unine.ch \\ SFM, University of Neuchâtel \\ Neuchâtel, Switzerland
}

\section{说 Springer}

\begin{abstract}
While some children of immigrants experience intergenerational upward social mobility, others do not. This paper explores the impact of parental and family involvement on offspring trajectories by contrasting families whose children experienced a highly mobile path, achieving tertiary education, against families whose children experienced low or no educational mobility. Focusing on within-group differences, the qualitative study analyses interviews conducted with twenty young persons and one of their parents in Kosovar families in Zurich, Switzerland, in 2013. Findings from our dyadic data reveal that educational outcomes are not only associated with parental educational attainment in the country of origin but also with professional mobility in the country of destination. This association is mediated by parenting styles, involvement and practices. While all parents show an important emotional involvement in their children's educational trajectory, significant within-group differences in the Albanian-speaking group appear with respect to their parenting styles, parental school involvement and resource mobilisation. We show that educational success is associated with an authoritative parenting style practised by parents of different educational background. By contrast, lack of educational success is common in families where parents cannot provide secure guidance to their children, whatever their previous educational achievement.
\end{abstract}

Keywords: Children of immigrants; Parenting styles; Family involvement; School outcomes; Social mobility; Within-group differences

\section{Introduction}

Ten years after its constitution, the Federal Commission for Foreigners published its first report on the "so-called second generation of foreigners" (CFE 1980), a document which marks the entry of this theme in the Swiss public arena. At the time young foreigners were mainly of Italian and Spanish origin, children of the workers that had fuelled the post-war industrial development of Switzerland. In the wake of the oil crisis in the 1970s, immigration to Switzerland decreased, but immigration flows soon recovered with newly recruited workers arriving in the 1980s and 1990s. They came predominantly from Portugal, Turkey and Yugoslavia (Wanner, Efionayi, and Fibbi, 2009) and occupied similar positions in the labour market than the Southern Europeans did earlier. As Swiss immigration policy turned towards the European Union, the conclusion of the Bilateral Agreements between Switzerland and the European Union in 1999 and the adoption of the Federal Act on Foreign Nationals in 2005 institutionalised a dual

(c) 2016 Fibbi and Truong. Open Access This article is distributed under the terms of the Creative Commons Attribution 4.0 International License (http://creativecommons.org/licenses/by/4.0/), which permits unrestricted use, distribution, and reproduction in any medium, provided you give appropriate credit to the original author(s) and the source, provide a link to the Creative Commons license, and indicate if changes were made. 
recruitment regime, one for EU-EFTA ${ }^{1}$ citizens and one for third country nationals. This polarisation appears also in the integration policy and public debates.

In this paper we focus on part of the 'new' second generation in Switzerland, children of Kosovar immigrants who arrived in the 1980s and 1990s (Fibbi, Topgül, Ugrina and Wanner, 2015 ). Workers from Kosovo came to work in agriculture and construction and initially were not distinguished from other workers from Yugoslavia. Only after the implosion of Yugoslavia and particularly in the context of the Kosovo war immigrants from Kosovo were recognized as a distinct group, specifically a problematic group. During the second half of the nineties, labour migration from Yugoslavia to Switzerland was made largely impossible while political tensions were piling up in the origin region. People from Kosovo arrived as asylum seekers, to a country where some political campaigns were branding migrants escaping widespread violence as "fake refugees". The outburst of war prompted family reunion of old-time labour migrants during a period of economic turndown in Switzerland. Relying on social welfare, Kosovars (be they asylum seekers or families) were frequently seen as an economic burden to the country, abusing the Swiss welfare system. The involvement of some young asylum seekers in drug dealing finished blemishing the reputation of the whole group (Burri Sharani et al., 2010).

Immigrants from the Albanian-speaking area of former Yugoslavia have been exposed to stigmatisation in the public opinion (Iseni 2013) and moreover their children to discrimination (Fibbi, Kaya, and Piguet, 2003). Against this context, the children of Kosovar descent have been the object of greater scepticism in the public arena fearing that they were less likely than other immigrant groups to perform well in school and enter the labour market (Fibbi, Lerch, and Wanner, 2011).

In quantitative studies on migrants, the need for sufficient observations often induces researchers to conflate Kosovars with other groups from South Western Balkans, rendering them invisible. Kosovars were already a regional sub-category of Yugoslavians in Tito's time, but when the political and later armed conflict within successor states of Yugoslavia lead to the constitution of a separate country in the Balkans, it also revitalised a distinctive sense of belonging as Kosovo Albanians, mostly culturally Muslims, facing an unfavourable and sometimes hostile immigrant-receiving context.

The number of Kosovo citizens in Switzerland is estimated to be around 170,000 in 2011, representing roughly $10 \%$ of the foreign population. Of these, some 40,000 are Swiss citizens of Kosovar origin (Iseni 2013), a group that does not appear in official statistic. The lens of nationality in official statistics is inadequate for accounting the present situation. Based on the TIES (The integration of European second generation) survey, Fibbi et al. (2015) indicates that around 75 per cent of native-born children of immigrants from Turkey and former Yugoslavia have acquired Swiss citizenship. ${ }^{2}$ Compared to other immigrants from former Yugoslavia, immigrants from Kosovo are characterised by lower levels of education: 10 per cent of the fathers and 20 percent of the mothers in our study attended only primary school, around half of what is found for immigrants from former Yugoslavia more generally. At the other end of the spectrum, 8 percent of Kosovar fathers attended tertiary education, compared to 13 percent across the Western Balkan. Consistently with this situation, school performance of children of Kosovar descent is below former Yugoslav average: the share of those who attended only compulsory schools or only very low-qualifying vocational training is highest, while the share of those who reached tertiary education is lowest. In this article, we 
concentrate on this stigmatised group while analysing some determinants of the second generation' school performances.

In the literature, it is common to study differences between immigrants and nonimmigrants and between immigrant groups (Alba, Sloan and Sperling, 2011; Crul, Schneider and Lelie, 2012; Kasinitz, Mollenkopf, Waters, and Holdaway, 2009; Portes and Fernandez-Kelly, 2008; Portes and Zhou, 1993). Comparing the experiences of different ethnic groups is a common research strategy in migration sociology, be it - most frequently the study of various origin groups in the same immigration country (convergent model, leading to a focus on between-group differences), or the study of the same origin group in many countries (divergent model, leading to a focus on between immigration country differences) (Green 2002). Both methodological approaches are instrumental in explaining why some national groups are slower to move up the occupational ladder (e.g. Rumbaut and Portes 2001) or to account for the importance of institutional arrangements in the receiving countries in shaping children of immigrant's outcomes (e.g. Crul et al. 2012).

By contrast, both approaches take the ethnic group as "natural" or "given" and neglect important within-group differences (Ali and Fokkema 2014; Telles and Ortiz 2008). Kasinitz et al. (2008: 22) argue that when it comes to integration patterns, withingroup differences are often as great as between-group differences, yet they focus exclusively on between group differences. More compellingly, Alba, Jiménez and Marrow (2014) urge scholars working on "immigrant adaptation in America (to) do a better job of accounting for heterogeneity, not just between but also within immigrant-origin populations" (Alba et al. 2014, p. 446). This plea applies certainly for European studies on immigration.

Macro and meso factors of immigrant integration focus on the opportunities offered by the reception context: various outcomes by similar socio-economic characteristics of migrants' children can be explained by official policy, public opinion, immigrant community structures, and the type of the city neighbourhoods. At the micro level, different outcomes are accounted for by dynamics of immigrant families: acculturation modes (Portes and Rumbaut 2001; Waters, Tran, Kasinitz and Mollenkopf 2010). These are reflected in the consonant or dissonant rhythm of local language learning and origin language retention. By its specific design the present research "holds constant" macro and meso factors: the field work concerns an age-homogenous group of young adults and their parents, from one single immigrant group, the Kosovars, in the context of the biggest city in Switzerland, Zurich, hosting the largest Kosovar community in this country: this allows us to focus on intra-group variability. The study concentrates on the micro dynamics of the family: in contrast to Portes and Rumbaut (2001), however, this study explores the role of parent-child relationships in relation to educational performance.

Our within-group comparison examines subgroups selected according to their degree of educational success. This is a consistent strategy to assess the importance of family dynamics in the shaping of educational careers by challenging all-inclusive cultural explanations of immigrant groups' outcomes. Our research questions revolve around the parental characteristics and socioeconomic status, parenting styles, and practices and their impact on children's educational achievement. What types of parent-child relations are relevant for educational attainment of children of Kosovar descent in Switzerland? Which are the determinants of parenting styles and practices? Does a 
form of protective parenting style appear besides the models identified in the canonical account?

\section{Theoretical background}

\section{Family dynamics and educational success: the conceptual tools}

Parenting styles are modes of family interaction. Baumrind (1971) studied children in elementary school and linked components of family interactions to cognitive competence. She identified three main parenting styles distinguishing two dimensions of demandingness and responsiveness. Demandingness captures guidance, the degree of parental control, and punitive or verbal disciplinary actions in relation to children's behaviour. Responsiveness expresses the degree of emotional support and affection parents show towards their children. Maccoby and Martin (1983) added neglectfulness to the picture, bringing the total to four parenting styles. The authoritative style is characterized by high responsiveness and high demandingness; the authoritarian style is characterized by low responsiveness and high demandingness; the permissive style is characterized by high responsiveness and low demandingness; while the neglectful style is characterized by low responsiveness and low demandingness. This approach of four parenting styles has been extended to adolescent children (Dornbusch, Ritter, Leiderman, Roberts and Fraleigh, 1987). Parenting styles are on one side largely influenced by the social origin of the parents and on the other side have an impact on the educational performance of the children: they are mediating variables explaining social reproduction. A wide array of research concludes that the authoritative parenting style is the most promising for the educational achievement of the children (Chan and Koo 2011; Darling and Steinberg 1993; Spera 2005).

Parenting style, conceived as emotional climate, is to be differentiated from parental practices which refer to specific behaviour used by parents to socialize their children (Darling and Steinberg 1993). Parental practices are a complementary area beyond school action in accounting for students' academic achievement. It is also an area of action, largely credited with having a positive effect on students' academic achievement. This construct consists notably of school related parental involvement as well as resource mobilization.

School-related opportunities for parental involvement range from conversation at home where parents and children discuss school programmes and activities to communication between parents and the school; from parental supervision such as monitoring homework or restrictions on children's going out to participation in school activities (Ho Sui-Chu and Willms 1996). Empirical research assessing the impact of parental involvement on educational achievement is far from conclusive, as some studies find positive effects of parental involvement on school learning, others found little, if any, measurable effect. In a meta-analysis on the topic Fan and Chen conclude: "The findings reveal a small to moderate, and practically meaningful, relationship between parental involvement and academic achievement. (...) parental aspiration/expectation for children's education achievement has the strongest relationship, whereas parental home supervision has the weakest relationship, with students' academic achievement" (Fan and Chen 2001, p. 1).

Parental support for children in their school career is given a concrete expression in the form of resource mobilization. The range can vary from full mobilization, when parents use both their own resources and seek external ones, to no resources mobilization 
at all. In intermediate situations parents activate exclusively resources available in their family, or exclusively seek external help. Drawing on external resources is a way of overcoming limited (personal) resources, but it also entails knowledge and competence to reach out for opportunities outside the family (Coleman 1988). Support inside the family matters as a parental practice where parents (or siblings) help in homework, cultivate discussion at home and supervise their children. Moreover, they also support decision-making during the educational trajectory of their children. Support outside the family implies a parental practice where parents seek support (paid or unpaid) outside of the core family. They may do this when support in the family reaches its limits.

The extension of concepts and research findings from majority families to minority and specifically to migrant families has raised a number of questions and criticisms, which challenged their universal pertinence and led to modifications of the categorization (Boos-Nünning and Karakasoglu 2004; Fibbi and Efionayi 2008; Spera 2005). Indeed, the study of parenting styles and practices in immigrant families has put into question the dominant conclusion according to which authoritative parenting style is the only conducive to better educational performances for children.

Pointing at possible socio-centrism and ethno-centrism of those constructs two different sets of arguments were put forward. Some argue that there are distinctive intergenerational relations peculiar to immigrant families (Kağıtçıbaşı 1990). In this line, Domenech-Rodriguez, Donovick and Crowley (2009) identified a specific "protective style" among Latino parents characterised by warmth, high demandingness but low levels of autonomy granting. While earlier theoretical and empirical work identified a deficit in terms of the childrearing practices of immigrant parents which called for compensatory actions (Lanfranchi 1995), recent studies consider parenting practices not only culturally defined patterns of behaviours and beliefs but also as adaptive responses to circumstances such as uncertainty and discrimination (Garcia Coll and Pachter 2002).

Studies on childrearing practices within migrant populations generally use a recurring scheme, where migrant families are compared to native families. Kao provides an illuminating example of the kind. Finding that children of immigrants often outperform their native counterparts, she examines "whether the relative advantage of children of immigrants can be traced to differences in the character of parent-child relationships" (Kao 2004, p. 427). Her quantitative study assesses the variability of parent-child interactions by race and ethnicity, partially explaining differential outcomes. Kao highlights cleavages in childrearing logics according to the ethnic background of the parents, and therefore lends credibility to the hypothesis that a specific parenting styles corresponds to specific (ethnic) groups. By contrast Lareau (2002) explored the impact of social class on the 'childrearing logics'. Cleavages in this respect do not run along ethnic lines: black and white parents behave in much the same way, according to the social class they belong to.

In this paper we take up two challenges: to assess whether elements of a specific parenting style are to be found in the population under study, Kosovar families in an urban European environment. The second challenge is to conceptualise social origin of migrant parents in a way that suitably accounts for their lives spanning across at least two countries. Moreover such a multifaceted conceptualisation of social origin aims at integrating social context and individual action as a way of tackling the problem of interrelating structure and agency. We thus rely on an agent-centred perspective in our 
comparative approach (Clark, Tracey and Lawton Smith 2002). The theoretical ambition of the present article is to contribute to shed light on the extent to which findings from research on majority family can be applied to migrant families.

\section{The study and its methodology}

Integrating two traditions in socialization research (Darling and Steinberg 1993), we study parental characteristics as well as specific parenting practices. On the one hand, parental social background is operationalized with the parents' educational achievement and position in the country of origin as well as with their present occupational status in the country of residence. The combination of these two factors is consistent with the migration experienced of the parents. On the other hand, parenting practices relate to schools as institutions and to the achievement of children. Both parental style and practices are influenced by the resources parents can mobilize to reach their goals. These resources, in turn, are dependent on the position parents occupy in the social stratification.

In this article, qualitative in-depths interviews are used to examine the impact of parent's parenting style and practices on the educational outcome of their children. ${ }^{3}$ The research is built around two groups of young adults of Kosovar origin who differ in their school outcomes: tertiary education vs. upper secondary education at the most. The contrast in the outcomes helps to investigate the hypothesized differences in parenting styles and practises as the micro-level explicating factor. Between January and April 2013, we conducted 20 interviews with young adults, aged 18 to 26, born in Switzerland or immigrated before the age of 9 as well as 20 interviews with one of their parents. A snowball sample of the young respondents was used, but diversified in terms of their level of education and gender. In order to study family influence on the children, the interviews concerned in each family the dyadic couple of a child and one of his or her parents. This approach has the advantage of considering both partners' perspective thus enhancing understanding of the parent-child relation (Weiss, Schnell, P and Ateş 2014). Interviews with the children were conducted in a different place and mostly by a different interviewer from interviews with the parents. All the 40 interviews were transcribed and coded.

The overall sample is evenly composed of men and women living in the greater Zurich area. Ten interview partners have no tertiary education: they are either in their last year of vocational training or just entered the labour market after (some) vocational training. In this group, men outnumber women: 8 vs. 2 persons. Ten interviewed persons are on their way to obtaining a degree at the university or at a university of applied sciences (German: Fachhochschule). Three of them have not yet started their degree but have already applied for a study place and were set to begin in summer 2013. Among the interviewees in tertiary education, women outnumber men: 8 vs. 2 persons. ${ }^{4}$ Table 1 reports the characteristics of the Kosovar young adults in our sample.

Of the parental interviews, 11 were conducted with the fathers and 7 with the mothers of the young adults. In two cases, both mother and father were present at the interview. The choice of father or mother was determined by the parental willingness to be interviewed. Nine of the 20 parents interviewed have reached tertiary education (they started or finished university studies in the home country upon graduating from Gymnasium); eight parents have had a secondary education (they attended post-compulsory education and learned a profession). Three parents attended only compulsory education. 
Table 1 The sample of Kosovar young adults

\begin{tabular}{llc}
\hline & Young Adults & $N=20$ \\
\hline Sex & Men & 10 \\
Age & Women & 10 \\
& Up to 20 & 7 \\
Education & Between 21 and 26 & 13 \\
& Secondary education & 10 \\
& Tertiary education & 10 \\
\hline
\end{tabular}

To identify the prevalent parenting style in each family and to overcome some inconsistencies in the narratives of the interviewees, we identify the main emphasis and frequencies of their argument. Furthermore, we base our analysis on the convergence or divergence in the parent-child dyad of the perception of family interactions. Parental involvement was analysed in two complementary perspectives. Psychological support provided by the parents to their children in school-related matters indicates emotional involvement with their children in his or her daily school life. It also reflects parents' interest in education. The parental role model is also a form of psychological support. Yet involvement also concerns communication and interactions the parents maintain with the school. Fieldwork outcomes lead us to distinguish between proactive behaviour and interactions limited to the formal fulfilment of school obligations. Parental involvement can thus take four distinct forms: two-sided action, when psychological support goes along with school interaction; lack of action, when both types of actions are neglected; intermediate forms of involvement concern only their children or only the school.

\section{Findings}

The findings are structured into a section on parents and parenting, followed by four portraits presenting the children's perspective. The portraits illustrate the typology established combining intergenerational relations and children's outcomes. The four identified types exemplified by the four cases cover the entire variation observed in our sample. ${ }^{5}$ For reasons of confidentiality we describe our young interviewees making use of invented yet contextualised names.

Dyadic analysis offers the unique possibility to assess overlaps and contrasts between the relations' partners, in our case parent and child (Eisikovits and Koren 2010). The two tertiary educated respondents, Zora and Afërdita, have an appreciation of their parent-child relation as authoritative which overlaps with their mother's. They are high achievers in spite of different family background. The two non-tertiary educated respondents, Flori and Visar, have an appreciation of their parent-child relation as permissive which contrasts with their father's view of themselves as being authoritarian. They are low achievers in spite of different family background.

\section{Zora and Afërdita: authoritative parents and high achievement}

Two women, Zora and Afërdita, experience an authoritative parenting style both in their and their parents' perspective, with full family mobilisation and proactive school intervention. These factors translate into intergenerational high status reproduction for Zora, who comes from a highly educated family, and into upward mobility for Afërdita, 
despite the limited educational resources of her parents and the downward mobility they faced upon migration to Switzerland.

\section{Zora}

Zora's parents came to Switzerland as asylum-seekers in 1992. Her mother had been a history and geography teacher in Kosovo. She started to work as a cleaner upon arrival, but later she completed her teaching diploma: today she works as an interpreter and taxi driver. She is active in community life by serving as the president of an Albanian women's club. Zora's father had been a skilled nurse in Kosovo. Since his diploma was not recognised in Switzerland, he first worked as a care worker. Later he managed to obtain a diploma: he has been active as registered nurse in a home for elderly person for the last five years.

Born in Switzerland, Zora was naturalised in 2005 at the age of 15. She graduated from the local Gymnasium and since primary school Zora knew she wanted to go to university. Her mother always said that her best time in her life was when she was studying. Now 22 years old, Zora is enrolled in French and English at bachelor level at the University of Zurich. At the moment she is spending a year abroad in the framework of the Erasmus programme.

Zora perceives her parents' attitudes as both demanding and responsive. She emphasises that her parents had strict rules concerning the permission to go out with friends, while her Swiss friends were allowed to go out without any restrictions. However, she is also aware of the fact that her parents' rules are more liberal than most other Kosovar parents living in Switzerland:

Zora finds her parents liberal in comparison to her countrymen. However, she emphasizes the importance of their openness as well as the cautious supervision of her parents. Zora's mother confirms this point:

"My children are not going anywhere before I have met the family. I want to know where my children are." (Zora's mother)

The parents provided psychological support and protected her in tense situations with the school authorities. Zora experienced unfair treatment in school: her primary teacher wanted to track her into Sekundarschule B (a lower secondary track leading to vocational work), but the mother was against the teacher's decision for her daughter:

"I think had I not acted as a mother, she as a child would have believed the teacher. You have a teacher saying "you're not fit for Gymnasium". And the mother says: (...) "No, don't listen to him. I know (...) I believe in you. You can do it". And they did it, but of course with lots of support." (Zora's mother)

Today Zora thinks her parents played a crucial role in her successful educational career. The parents supported their child by helping out with homework for example; they also organised family-external support, such as hiring a private teacher, to prepare Zora for the entering exam to Gymnasium.

"My parents have contributed a lot to get me there where I'm now. Because alone, as student you don't have the possibility to stand up for yourself. You just believe the teacher." (Zora) 
Zora represents the first type of family relations, associated with intergenerational preservation of high social status in spite of parental initial occupational downward mobility due to the migration process. Mother and daughter agree in describing the mode of parentchild interactions as authoritative; in this climate the parents provided a strong psychological support to their daughter in her school career and mobilised both family-internal and family-external resources when deemed necessary. The parents were also capable to stand by the young woman, when they asserted themselves in the relations with the teacher. Finally they exerted a watchful control over her company: this form of social control proved important to her academic success (Coleman 1988). This is clearly different from the protective parenting style identified by Nauck (1999) as distinctive in Turkish families in Germany or by Domenech-Rodriguez et al. in Latino families in the United States.

\section{Afërdita}

Afërdita's father came to Switzerland 1986 as seasonal worker and was joined later by his wife. Afërdita's father is now a disabled pensioner. Her mother has been a skilled shoemaker in Kosovo; upon arrival in Switzerland she worked in a restaurant as a temporary staff member. Today she is a caretaker and cleaner in a private household.

Afërdita arrived as an infant in Switzerland. She holds a Swiss passport since 2012. Today 22 years old, she is enrolled at the Faculty of Arts at the University of Zurich. She has a smooth educational trajectory. Her mother was always attentive and showed interest for her daughter's school matters. Particularly in primary school she was present for homework and gave their daughter intensive support, especially in mathematics. Her parents regularly stressed the importance of school. Afërdita liked to go to school and always knew she wanted to go to university.

Both mother and daughter describe the parenting style as responsive and demanding. The mother explains what a good upbringing looks like to her:

"A good education is to be there for your children. Listen to you children's opinion. Help, if necessary. It is important that children are honest, but you have to be honest with him/ her too. A good education is also when children feel that her mother or father supports them. If my child is afraid to tell me something, this is not a good education." (Afërdita's mother)

For Afërdita's mother it is important that her children choose their goals:

“I'd like the children to have a goal. It doesn't matter if university or a job (...) I told her, tell me what goal you have, and I'll support you! (...) I'm aware that not everybody can go to university. Of course I'd be happy if they both went to uni, but I'm not putting pressure." (Afërdita's mother)

Afërdita's mother always provided psychological support in school matters. In situations of interpersonal tension she protected her daughter, contacting the professor when Afërdita was bullied by her schoolmates or discussing homework with the teacher.

"Once in school, my daughter was struggling with a maths problem. I showed her how to solve it. No, not like that, she (the daughter) said: in a different way. I told her the result was correct. No, my daughter said. The teacher apparently looked at 
the approach. I went to the teacher and said: why are you making it so difficult for the children? (Apparently nobody in class could solve this problem). Then I solved it on the blackboard, with the teacher. And the teacher said: yes, your approach is correct, too." (Afërdita's mother)

Afërdita could rely on her mother's backing. When the family resources reached their limits, her parents also organised external support. They also provided her with guidance in decision-making during her school trajectory.

Afërdita represents the second type of family relations in which the children experience intergenerational upward mobility in spite of an unfavourable family background. Mother and child both characterise family interactions as authoritative. The mother provides all types of support: emotional, psychological and practical; she mobilises both family-internal and family-external resources when necessary. When Afërdita was treated bullied at school, the parents protect her by seeking an active dialogue with the school. Such intensive resource mobilisation contributed to the Afërdita's educational upward mobility.

\section{Flori and Visar: permissive parents and low achievement}

The two men, Flori and Visar, evaluate their parent-child relation quite differently from theirs fathers: they both describe their father as not demanding yet emotionally involved, while the fathers regret having been strict but not responsive enough to their sons. Their disagreement indicates a parent-child relation that is unsatisfactory for both sides. Under these circumstances, the parental educational background seems to have a stronger influence than in the case of the women. Flori's father, who holds a tertiary education, can rely on family resources to support his son in school and manages to keep interactions with school. His son is not able to reproduce the educational level of the parents, yet he is attending vocational training. Visar's father is less educated than Flori's: he complies with school requirements yet he cannot support personally his son in school matters and is unable to mobilize external help. With no upper secondary qualification his son is drifting from one unqualified job to another.

\section{Flori}

Flori's father came to Switzerland in the late 1980s, after having completed his law degree, as he could not find a job in Kosovo. With a seasonal permit he first worked as brick layer; today he is foreman in the construction business. Flori's mother never entered the labour market.

Flori arrived in Switzerland at the age of 2 and grew up in a city in the canton of Zurich. He attended primary school in this city, where he felt discriminated by his school teacher. After Sekundarschule B, Flori found it difficult to find an apprenticeship: he unsuccessfully sent more than 200 applications. He then decided to attend an extra school year while applying for naturalization, in the hope that holding a Swiss passport would increase his chance in the job market. Flori considers the search for an apprenticeship to be the hardest time in his life so far. Today 19 years old, he is attending his last year of vocational training as a service technician. Yet he plans to complete another vocational training, for instance as clerical assistant, as a friend of his suggested him. 
Flori describes his parents' attitudes toward him as responsive. He emphasises their emotional support especially when he was looking for his apprenticeship and was systematically turned down. Yet he thinks that his parents were not very demanding. By contrast, his father regards his parenting style in general as demanding but not sufficiently responsive. Reflecting on his educational methods, he affirms:

"I'd have used a different method for explaining the homework. I'd have taken more patience and time for the explanations." (Flori's father)

The most striking feature in Flori's case is the opposing appreciation of the parenting style by father and son. Many stories of children who did not make it to tertiary education present such a contrasted evaluation of family interactions.

Flori's parents interacted with school teachers; however, they were not proactive in school matters. His father was not happy with the teacher's tracking decision for his child and the argument that it is better to be a good student in an easier type of school than a bad student in a more demanding level. In spite of his dear wish to see his son tracked in a higher level, the father did not contest the teacher's decision.

Flori could count on family internal support in school matters and homework, especially from his elder siblings. But he did not receive any family-external help, when he reached the limits of his family's informal support.

Flori represents the third type of family relations, associated with children intergenerational downward mobility. In spite of his law studies in Kosovo, Flori's father experienced severe deskilling upon migration and never managed to regain his social status. Father and child do not agree in their appreciation of the parenting style: the son feels that his caring father failed to provide a secure guide into school and professional life, as he tends to describe a "permissive" parent, whereas his father thinks he was authoritarian. The parents complied with the requirement of school involvement, yet they relied on a rather passive, subdued attitude. They nevertheless provided as much support as possible in school matters but lacked the capability to reach out for further, external support in more challenging situations.

\section{Visar}

Visar's parents came to Switzerland in 1983. His father, a skilled mechanic for tractors in Kosovo, immigrated as a seasonal worker. As he could not resume working in his learned trade, he is now a warehouse manager. Today he regrets his decision to have migrated and he expresses disappointment about his son; he is pessimistic with respect to the perspectives of his family and his son. Visar's mother is a housewife.

Visar came to Switzerland when he was 3 years old. He had a troublesome school career. Primary school was a "nightmare" for Visar, since he often experienced discrimination. Though the other pupils bullied him, his primary teachers never protected him in such situations. Visar regards himself as a 'black sheep' among white sheep. In his further educational path he never developed any interest for school. In this context Visar went to the lowest track of lower secondary school. Upon completing compulsory school, he could not find an apprenticeship because of his low grades. He started to work in the warehouse where his father is employed. Visar did not keep his job for a long time, and 
has since moved from one temporary job to another. Since 1999 Visar holds a permanent residence permit. Now 23 years old, he has little hope of improving his professional life. Yet he hopes his children will do better.

Visar's father thinks he was strict.

"Education in my view is: To look after the children, to take care of the children so that they are fine. The other thing is pressure. You have to show them what their duties are. (...). It is not about violence or being tough, but simply to reward or punish the children. Take away their favourite things or giving them a present, so that they learn from their mistakes. For example, if they had bad marks in school." (Visar's father)

Yet he regrets not having been more responsive to his children:

"I'd do many things differently. Most of all, take more time for my children. Spend more time with the children. Be open with them and try to get their confidence."

(Visar's father)

Visar's perception of the way he was brought up by his parents is quite different, as he describes his parents as responsive. His father is his 'best friend'. Yet he did not perceive his father as demanding, as he was always away, working on two jobs from 5 in the morning to 11 at night.

"My education was a bit of a flop. I was the youngest, so it was always something in between. They weren't really strict with me, always a bit too nice. Dad didn't have much time, so we were always with mum and she anyway was too nice. (...). We actually only respected my dad, but he was never home. " (Visar)

Visar's father regularly kept in contact with the school, yet he could not protect his son, nor could he give Visar any support in school matters; nor could he provide sufficient psychological support, as Visar completed his difficult school path. Visar felt that he could not count on support or help from his family or from outside of the family.

Visar's story illustrates the fourth type of family relations, associated with intergenerational lack of mobility. Father and son describe the mode of family interaction in contradictory terms. While the father describes himself as authoritarian and demanding with little responsiveness, the son characterises the parents to have been little demanding but responsive. The parents assumed a helpless and hopeless attitude, being overwhelmed by the task of bringing up the child and being acutely aware of their lack of resources.

\section{Discussion}

The paper assessed whether specific parenting styles could be observed in migrant families and how these parenting styles mediate intergenerational reproduction among migrants. We find no evidence for a specific parenting style in Kosovar families: the established typology of parenting styles can account for all the immigrant families in our sample. Moreover, the association between parenting style and children's education success assessed in the mainstream literature is confirmed: our findings show the children who perform best (examples of Zora and Afërdita), experienced a similar, 
authoritative, parenting style at home, in spite of the fact that their parents have a quite different educational background. By contrast, the children who perform worse (examples of Flori and Visar) experience a permissive parenting style at home.

Our findings further question the linear association between parental educational achievement and parenting styles posited by Nauck (1990) and Lareau (2002). This difference in findings may be due to the conceptualisation of parental status in the mainstream literature, which is inadequate in the case of migrant parents. School qualifications obtained in the country of origin represent major structural resources/ limitations for migrants, but a static measure like the parental level of education acquired in the country of origin is a poor indicator for the social background of parents who experienced a radical change in their life course as a consequence of migration. In their present country of residence, structural constraints provide a new context to parental agency.

A combination of parental education and occupational mobility upon migration is better suited to the lives of migrants which span two countries. We argue that this provides a more convincing explanation for the association between the structural position of parents and the outcomes of their children, mediated by parenting styles. Possibly the professional experience upon migration of the parents has a moderating influence on the initial level of education in determining the parenting style: the downward mobility of Flori's father and a frustrating labour trajectory of Visar's father represent stressful situations which constraint their agency as parents. They lack the resources to provide guidance to their children and to protect them against unfair treatment.

The intersection of the two status dimensions - parental education and occupational mobility upon migration - reveals the diversity and difference within the ethnic group under study. This methodological device is inspired by the approach of intersectional complexity that McCall describes as "intracategorical", characterised by a "focus on particular social groups at neglected points of intersection (...) in order to reveal the complexity of lived experience within such groups" (McCall 2005, p. 1774).

Interviewing parent-child dyads was instrumental in identifying the degree of convergence in their appreciation of the parenting style. In all the examples of high educational achievement, the interviewed parents and children deliver a matching account of the style of the parent-child relations. By contrast, in all the cases of children with low educational achievement the appreciation of family relations provided by parents and children differ: parents say that they have been quite strict towards their children, while the children qualify their parents as warm yet not very demanding. The answers point at different understanding of what it means to be demanding: children conceive it as orientation and goal setting, whereas parents think of it in terms of discipline and control. Such a contrasted appreciation appears in families of parents with low educational background, like in the example of Visar, as well as in families where the parents have a tertiary education but experienced downward mobility upon migration, as in Flori's case. Uslucan, Fuhrer and Mayer (2005) report that contrasting parent-child appreciations of educational style are frequent in Turkish families, more so than in German families; they are interpreted as tensions in intergenerational relations. In our study, divergent evaluations concern unsuccessful young men. Steinbach and Nauck (2005) observe a weaker transmission of attitudes and behaviours in the men's dyads than in the women's. 
Turning to parental involvement, we observe that all the interviewed children feel they enjoyed psychological support. Yet the way parents invested in family-school relations was different, reflecting their capacity to agency: some parents were proactive, while others were rather passive. Proactive parental engagement in school was found in cases of children performing well, regardless of their mothers' educational background. These children found protection and support when they faced unfair treatment and bullying. This is not the case for less performing children. Their parents did engage in school affairs, yet mostly passively. As for resource mobilisation, parents of the educationally successful children were able to arrange external support in order to complement their own engagement for their children. In Visar's and Flori's families, for example, internal support was absent - or limited to sibling's help -, and parents lacked the knowledge and (possibly) network to mobilise possible external resources.

\section{Conclusion}

This paper explored how micro-level factors, intergenerational family interactions, influence the educational trajectories of children in Kosovar families in Zurich. This group is of special interest because of its internal diversity, since it is composed of both labour migrants and asylum seekers, and occupies a stigmatized position among the immigrant groups in Switzerland.

Some authors challenged the adequacy of transferring parenting styles from majority to immigrant families and identified a specific form of intergenerational relations in these families. By focusing on within-group differences, the results of this study question this hypothesis. The parenting styles observed among Kosovar families in Zurich correspond to the ones identified among majority groups. Moreover, as in the literature on the mainstream population, the authoritative style is the one systematically associated with higher educational performance of the immigrant children.

In the mainstream population, intergenerational relations and practices are largely determined by parental educational background. Our findings concerning minority families however contest such a linear relationship. In Kosovar families in Zurich parenting styles and practices appear connected not to a fixed social origin but to the social trajectories of migrant parents across origin and destination countries and the radical change in their life course as a consequence of migration. Structural determinism gives thus way to an agent-centered perspective which allows exploring the range of diversity and difference within the ethnic group.

Such a result is strictly related to the peculiar comparative design of the study. Intergroup comparisons are the most frequent type of comparisons in studies of immigrant populations. When the observation embraces majority and (disadvantaged) minority groups, the result is a strong polarization in their educational and occupational statuses. Consequently, within-group differences tend to be overlooked contributing to a stereotyped homogenised and "culturalised" perception of both groups.

The explorative nature of this qualitative fieldwork suggests caution on the generalizability of the findings. Yet the validity for our results rests upon the quality of the sample which was built according to the characteristics pertinent for our study purpose, i.e. contrasted on the educational outcomes. Its representativeness is to be appreciated in terms of social processes. 


\section{Endnotes}

${ }^{1}$ European Free Trade Association

${ }^{2}$ In Switzerland, the survey was conducted in 2007-2008 with children of Turkish and former Yugoslavian descent. Its sample was drawn from official statistics complemented by name recognition; it allows identifying youth according to the place of birth of the father www.tiesproject.eu. Note that there is no jus soli in Switzerland, nor any easing of naturalisation conditions for children of immigrants. Naturalisation is an individual, selective procedure.

${ }^{3}$ The funding for this field research was provided by collaboration with the Swiss NCCR Lives. The National Centre of Competence in Research "LIVES - overcoming vulnerability: life course perspectives" studies the effects of the post-industrial economy and society on the development of situations of vulnerability using a longitudinal and comparative approach. http://www.lives-nccr.ch/.

${ }^{4}$ Strikingly women outnumber men among the educationally successful young persons in our qualitative sample. However we refrain from interpreting this result in terms of gender for methodological reasons. The snowball sample might bear a gender bias introduced the Albanian-speaking persons - a young woman and a middle-age man -recruited for conducting interviews with Albanian-speaking parents. Moreover quantitative considerations are to be handled with care in qualitative studies, especially when not supported by other literature results. Indeed a recent literature review acknowledges that studies do not reach unanimous results on gender differences in school attainment among children of immigrants (Bader and Fibbi 2012). The TIES study in Switzerland does not provide support for the hypothesis that secondgeneration girls achieve higher levels of education than their fellow countrymen, but there is no evidence either for the competing hypothesis of girls reaching lower levels of achievement than boys as a result of traditional gender roles. It appears that girls perform better in compulsory school and possibly in upper secondary, but this advantage vanishes at subsequent levels of education (Fibbi et al. 2015).

${ }^{5}$ The presentation of the cases follows the same procedure used by Crul, Zhou, Lee, Schnell and Keskiner (2012) as well as by Zhou, Lee, Tafoga-Estrada, Vallejo, and Xiong (2008).

Competing interests

The authors declare that they have no competing interests.

Authors' contributions

Both authors have actively participated in the field work and the writing of the article and have approved the final manuscript.

\footnotetext{
Authors' information

Rosita Fibbi graduated as Doctor in Political sciences at the University of Rome, La Sapienza. She further studied in Zurich and Geneva. She teaches Sociology of Migration at the University of Lausanne and is Senior Researcher and Project Manager at the Swiss Forum for Migration and Population Studies at the University of Neuchâtel. Her research interests include integration trajectories of immigrants and their children, discrimination on the labor market, migrant families and intergenerational relations. She recently co-authored "Getting ahead through various avenues: Examining educational and occupational pathways of the 'new' second-generation in Switzerland." Journal of International Migration and Integration (2015) and The new second generation: Youth of Turkish and former Yugoslav descent in Zurich and Basel. Amsterdam: Amsterdam University Press (2015).

Jasmine Truong is a PhD candidate at the Department of Geography, University of Zurich. Her research interests include youth studies, social media, care migration. Recent publications include "Neoliberal austerity and the marketisation of elderly care" (Social \& Cultural Geography, 2015).
} 
Received: 15 March 2014 Accepted: 7 March 2015

Published online: 05 October 2015

\section{References}

Alba, R, Jiménez, TJ, \& Marrow, HB. (2014). Mexican Americans as a paradigm for contemporary intra-group heterogeneity. Ethnic and Racial Studies, 37(3), 446-466.

Alba, R, Sloan, J, \& Sperling, J. (2011). The integration imperative: the children of low-status immigrants in the schools of wealthy societies. Annual Review of Sociology, 37, 395-415.

Ali, S, \& Fokkema, T. (2014). The importance of peers: assimilation patterns among second-generation Turkish immigrants in Western Europe. Journal of Ethnic and Migration Studies(ahead-of-print), 1-24.

Bader, D, \& Fibbi, R. (2012). Les enfants de migrants: un véritable potentiel [Children of immigrants: a true resource]. Berne: Conférence suisse des Directeurs de l'Instruction Publique.

Baumrind, D. (1971). The influence of parenting style on adolescent competence and substance use. Journal of Early Adolescence, 11, 56-95.

Boos-Nünning, U, \& Karakasoglu, Y. (2004). Viele Welten Leben. Lebenslagen von Mädchen und jungen Frauen mit griechischem, italienischem, jugoslawischem, türkischem und Aussiedlerhintergrund. [Living in many worlds. Lifesituation of girls and young women chidren of Greek, Italian, Yugoslavian, Turkish or resettler descent]. Berlin: Bundesministerium für Familien, Senioren, Frauen und Jugend.

Burri Sharani, B, Efionayi-Mäder, D, Hammer, S, Pecoraro, M, Soland, B, Tsaka, A, \& Wyssmüller, C. (2010). Die kosovarische Bevölkerung in der Schweiz [People from Kosovo living in Switzerland]. Bern: Bundesamt für Migration.

CFE. (1980). Les jeunes étrangers - la deuxième génération : problèmes et solutions possibles [Young foreigners : the second generation. Problems and possible solutions] Secrétariat de la CFE (p. 12). Berne: Information Commission fédérale des étrangers.

Chan, TW, \& Koo, A. (2011). Parenting style and youth outcomes in the UK. European Sociological Review, 27(3), $385-399$. doi:10.1093/esr/jcq013.

Clark, GL, Tracey, P, \& Lawton Smith, H. (2002). Rethinking comparative studies: an agent-centred perspective. Global Networks, 2(4), 263-284. doi:10.1111/1471-0374.00041.

Coleman, J. (1988). Social capital in the creation of human capital. American Journal of Sociology, 94, 95-120.

Crul, M, Schneider, J, \& Lelie, F (Eds.). (2012). The european second generation compared. Does the integration context matter? Amsterdam: Amsterdam University Press.

Crul, M, Zhou, M, Lee, J, Schnell, P, \& Keskiner, E. (2012). Success against the odds. In M Crul \& JH Mollenkopf (Eds.), The changing face of world cities: young adult children of immigrants in Europe and the United States (pp. 25-45). New York: Russell Sage Foundation.

Darling, N, \& Steinberg, L. (1993). Parenting style as context: an integrative model. Psychological Bulletin, 113(3), $487-496$. doi:10.1037/0033-2909.113.3.487.

Domenech-Rodriguez, M, Donovick, M, \& Crowley, S. (2009). Parenting styles in a cultural context: observations of "protective parenting" in first-generation latinos. Family Process, 48(2), 195-210.

Dornbusch, SM, Ritter, PL, Leiderman, HP, Roberts, DF, \& Fraleigh, MJ. (1987). The relation of parenting style to adolescent school performence. Child Development, 58(5), 1244-1257.

Eisikovits, Z, \& Koren, C. (2010). Approaches to and outcomes of dyadic interview analysis. Qualitative Health Research, 20(12), 1642-1655.

Fan, X, \& Chen, M. (2001). Parental involvement and Students' academic achievement: a Meta-analysis. Educational Psychology Review, 13(1), 1-22. doi:10.1023/a:1009048817385.

Fibbi, R, \& Efionayi, D. (2008). Questions d'éducation dans les familles migrantes. [Educational issues in migrant families]. In COFF (Ed.), Familles - Education - formation [families, upbrining, Education] (pp. 48-66). Berne: Commission fédérale de coordination pour les questions familiales.

Fibbi, R, Kaya, B, \& Piguet, E. (2003). Le passeport ou le diplôme? Etude des discriminations à l'embauche des jeunes issus de la migration. [Passport or qualification? Study on hiring discrimination concerning children of immigrant descent]. Neuchâtel: Forum suisse pour l'étude des migrations et de la population.

Fibbi, R, Lerch, M, \& Wanner, P. (2011). School qualifications of children of immigrant descent in Switzerland. In R Alba \& M Waters (Eds.), New dimensions of diversity: the children of immigrants in north America and western Europe (pp. 110-134). New York: New York University Press.

Fibbi, R, Topgül, C, Ugrina, D, \& Wanner, P. (2015). The new second generation: youth of turkish and former yugoslav descent in Zurich and Basel. Amsterdam: Amsterdam University Press.

Garcia Coll, C, \& Pachter, LM. (2002). Ethnic and minority parenting. In MH Bornstein (Ed.), Handbook of parenting (Vol. 4 Social conditions and applied parenting (pp. 1-20). Mahwah, New Jersey: Lawrence Erlbaum Associates.

Green, NL. (2002). Repenser les migrations. [Rethinking migrations]. Paris: Presses universitaires de France.

Ho Sui-Chu, E, \& Willms, JD. (1996). Effects of parental involvement on eighth-grade achievement. Sociology of Education, 69(2), 126-141.

Iseni, B. (2013). Albanian-speaking transnational populations in Switzerland: continuities and shifts. Southeast European and Black Sea Studies, 13(2), 227-243. http://dx.doi.org/10.1080/14683857.2013.802174.

Kağıtçıbaşı, C. (1990). Family and socialisation in cross-cultural perspective: a model of change. In JJ Berman (Ed.), Cross-cultural perspectives: Nebraska symposium on motivation 1989 (pp. 135-210). Lincoln: Nebraska University Press.

Kao, G. (2004). Parental influence on the educational outcomes of immigrant youth. International Migration Review, 38(2), 427-449.

Kasinitz, P, Mollenkopf, J, \& Waters, M. (2008). The second generation advantage: the children of immigrants inherit the city. Cambridge, Mass.: Harvard University Press.

Kasinitz, P, Mollenkopf, JH, Waters, MC, \& Holdaway, J. (2009). Inheriting the city. The children of immigrants come of Age. New York: Russell Sage Foundation. 
Lanfranchi, A. (1995). Immigranten und Schule. Transformationsprozesse in traditionales Familienwelten als Voraussetzung für schulisches Ueberleben von Immigrantenkindern. [Immgrants and School. Transformation processes in traditional family worlds: a prerequisite for school survival of children of immigrants]. Opladen: Leske + Budrich.

Lareau, A. (2002). Invisible inequality: social class and childrearing in black families and white families. American Sociological Review, 67(5), 747-776.

Maccoby, EE, \& Martin, JA. (1983). Socialization in the context of the family: parent -child interaction. In PH Mussen (Ed.), Handbook of child psychology (Vol. 4, pp. 1-101). New York: Wiley.

McCall, L. (2005). The complexity of intersectionality. Signs Journal of Women in Culture and Society, 30(3), 1771-1800.

Nauck, B. (1990). Eltern-Kind-Beziehungen bei Deutschen, Türken und Migranten. [Relations between parents and children in German, Turkish and Migrantfamilies]. Zeitschrift für Bevölkerungswissenschaft, 16, 87-120.

Nauck, B. (1999). Sozialer und intergenerativer Wandel in Migrantenfamilien in Deutschland. Migranten und Flüchtlinge: Eine familienwissenschaftliche Annäherung. [Social and intergenerational change in migrant families living in Germany. Migrants and Refugees, a scientific family approach]. ÖlF Schriftenreihe, 8, 13-69.

Portes, A, \& Fernandez-Kelly, P. (2008). No margin for errors: educational and occupational achievement among disadvantaged children of immigrants. The Annals of the American Academy of Political and Social Science, 620, 7-36.

Portes, A, \& Rumbaut, RG (Eds.). (2001). Legacies: the story of the immigrant second generation. Los Angeles and New York: University of California Press.

Portes, A, \& Zhou, M. (1993). The new second generation: segmented assimilation and its variants among post-1965 immigrant youth. Annals of the American Academy of Political and Social Science, 530(1), 74-96.

Rumbaut, RG, \& Portes, A (Eds.). (2001). Ethnicities. Children of immigrants in america. Los Angeles: University of California Press.

Spera, C. (2005). A review of the relationship among parenting practices, parenting styles, and adolescent school achievement. Educational Psychology Review, 17(2), 125-146. doi:10.1007/s10648-005-3950-1.

Steinbach, A, \& Nauck, B. (2005). Intergenerationale transmission in migrantenfamilien [intergenerational transmissions in migrant families]. In U Fuhrer \& H-H Uslucan (Eds.), Familie, Akkulturation und Erziehung: migration zwischen Eigen-und Fremdkultur [acculturation and upbringing: migration between own and other's culture] (pp. 111-125). Stuttgart: Kohlhammer Verlag.

Telles, EM, \& Ortiz, V. (2008). Generations of exclusion: mexican-americans, assimilation, and race: Russell sage foundation.

Uslucan, HH, Fuhrer, U, \& Mayer, S. (2005). In T Borde \& M David (Eds.), Erziehung in Zeiten der Verunsicherung. [Education in times of uncertainty] (pp. 65-88). Frankfurt/Main: Kinder und Jugendliche mit Migrationshintergrund.

Wanner, P, Efionayi, D, \& Fibbi, R. (2009). Switzerland. In H Fassmann, U Reeger, \& W Sievers (Eds.), Statistics and reality (pp. 151-166). Amsterdam: AUP.

Waters, M, Tran, VC, Kasinitz, P, \& Mollenkopf, J. (2010). Segmented assimilation revisited: types of acculturation and socioeconomic mobility in young adulthood. Ethnic and Racial Studies, 33(7), 1169-1193.

Weiss, H, Schnell, P, \& Ateş, G. (2014). "“'Wie die Eltern, so die Kinder?" Zur Bedeutung familiärer Transmission im gesellschaftlichen Integrationsprozess". In H. Weiss, P. Schnell, \& G. Ateş (Eds.), Zwischen den Generationen. Transmissionsprozesse in Familien mit Migrationshintergrund (pp. 7-22). Wiesbaden: Springer Verlag.

Zhou, M, Lee, J, Tafoga-Estrada, R, Vallejo, JA, \& Xiong, Y. (2008). Success attained, deterred and denied: Divergent Pathways to Social Mobility in Los Angeles' new second generation. The Annals of the American Academy of Political and Social Science, 37-61.

\section{Submit your manuscript to a SpringerOpen ${ }^{\circ}$ journal and benefit from:}

- Convenient online submission

- Rigorous peer review

- Immediate publication on acceptance

- Open access: articles freely available online

- High visibility within the field

- Retaining the copyright to your article 